\title{
Effectiveness of gamma and electron beam irradiation techniques in extending the shelf-life of pasteurized sausage in natural conditions
}

\author{
Phan Phuoc Hien ${ }^{1}$, Đoan Thi The ${ }^{2}$, Huynh Thi Phuong Thanh ${ }^{3}$ \\ ${ }^{1}$ Research Center for Development of Precious and Medicinal Resources, Institute of Environment and Resources, National University, HCM \\ City Vietnam \\ ${ }^{2}$ Division of Research and Development, Research and Development Center for Radiation Technology, HCM City Vietnam \\ ${ }^{3}$ Biotechnology Department, Nong Lam University, HCM City Vietnam
}

Email address:

pphien@gmail.com (P. P. Hien)

\section{To cite this article:}

Phan Phuoc Hien, Đoan Thi The, Huynh Thi Phuong Thanh. Effectiveness of Gamma and Electron Beam Irradiation Techniques in Extending the Shelf-Life of Pasteurized Sausage in Natural Conditions. Journal of Food and Nutrition Sciences. Special Issue: Food Processing and Food Quality. Vol. 3, No. 1-2, 2015, pp. 135-139. doi: 10.11648/j.jfns.s.2015030102.35

\begin{abstract}
Co-research group in cooperation between Nong Lam University and VINAGAMMA Center in Ho Chi Minh City carried out this irradiation experiments on instant food by using two different irradiation techniques. The stationary irradiation sourced from $\mathrm{Co}^{60}$ was applied at different doses $(1.0 \mathrm{kGy}, 2.5 \mathrm{kGy}, 5.0 \mathrm{kGy})$ to ready to eat pasteurized sausage and mobile irradiation sourced from Electron -Beam (EB) was applied at same doses to pasteurized sausage in order to prolong the shelflife of the products. After irradiation, the microbial and sensory quality of sausage was analyzed and evaluated monthly upto six months of storage in natural conditions. The microbial parameter included total aerobic bacteria, yeast, mold, E. coli, clostridium spp. and sensory parameters of color, structure, smell, and taste was evaluated for each dose applied upto six months of storage at natural condition. The study results showed that despite the irradiation sources, application of 5.0kGy dose of irradiation was able to extend the shelf life of ready to eat sausages up to six months at natural condition without compromizing the microbial and sensory parameters. Thus, this irradiation technology could be applicable in extending the shelf life of meat products.
\end{abstract}

Keywords: Stationary Irradiation, Mobile Irradiation, $\mathrm{Co}^{60}$, EB (Electron Beam), Pasteurized Sausage, Yeast, E. coli, Mold, Total Aerobic Bacteria (TAB), Clostridium spp, and Sensory parameter

\section{Introduction}

Ready-to-eat pasteurized sausage is getting more and more popular because of its convenience, high nutrition content and safety; therefore, the requests of food hygiene safety and shelf-life are very important for consumers and producers (QCVN 8-3: 2012/BYT Vietnam). The current practices in Vietnam could able to store ready-to-eat package sausages only 3 months in natural condition. This three months storage in natural condition is not enough to export these products to the international market. Therefore, the producer wanted at least 6 months to one year shelf-life for their products to export in international market. To overcome this challenges use of irradiation is thought to be the appropriate techniques in extending the shelf life of ready to eat food products. In addition, The U.S. Food and Drug Administration has approved the use of irradiation up to $4.5 \mathrm{kGy}$ and $7 \mathrm{kGy}$ to control bacterial pathogens on refrigerated meat and frozen meat, respectively (FDA 1997). Furthermore, many study result reported that food irradiation using electron beam - EB, gamma rays or $\mathrm{X}$ rays to inhibit and reduce the growth of harmful microorganisms in ready-to-eat food products and many countries including USA already permitted irradiated food to be sold in the market with proper labeling. (Jo et al., 2000, 2002; Bari et al., 2006). On the other hand, Bari et al (2006) reported that higher dose $(>5.0 \mathrm{kGy})$ of irradiation has a negative effect on the organoleptic qualities of the meat and therefore, in this study we used maximum $5.0 \mathrm{kGy}$ of irradiation.

Based on the above mentioned fact we carried out this 
study using gamma and electron beam irradiation to prolong shelf-life of pasteurized sausage stored in natural condition.

\section{Materials and Methods}

\subsection{Materials}

\subsubsection{Sample Preparation}

Pasteurized sausage: $25 \mathrm{~g}$ and $35 \mathrm{~g}$ (collected from supermarkets in Ho Chi Minh City)

\subsubsection{Equipment and Tools}

Equipment: drying cabinet, incubator, autoclave, refrigerators, micropipette...

Tools: test tubes, petridishes, stirring rod, flask, alcohol lamps, absorbent cotton...

\subsubsection{Chemicals}

Alcohol $96^{\circ}$, distilled water, agar, n-butanol, TBA-reagent (TBA: Thiobartiburic acid).

\subsubsection{Culture Medium}

Plate Count Agar, Sabouraud Dextrose Agar, Brilliant Green Bile Agar, Iron Sulphite Agar, Peptone dilute solution. (Tran Linh Thuoc. 2006; TCVN 5165 - 90)

\subsection{Methods}

\subsubsection{Irradiation Techniques}

The sausages samples were irradiated from Co-60 source (SVST-Co60/B; made in Hungary) and $1.0 \mathrm{kGy} ; 2.5 \mathrm{kGy}$ and $5.0 \mathrm{kGy}$ doses were applied. Same doses were applied to the sausages samples using EB accelerator (UERL-10-15S2; made in Russia). All the samples were irradiated at VINAGAMMA Center of Ho Chi Minh City.

\subsubsection{Experimental and Anlytical Methods}

Sausage samples were irradiated and the changes of microbiological and sensory quality of irradiated sausage was analyzed and evaluated monthly up to 6 months of storage at room temperature: $25-27^{\circ} \mathrm{C}$ (TCVN 7247: 2003: CODEX STAN 106-1983).

\subsubsection{Determination of the Optimal Irradiation dose for the Extended Shelf-Life with the Better Quality}

The optimal irradiated dose has been determined by analyze monthly during six months to evaluate quality changes of irradiated sausage stored in natural condition in Ho Chi Minh city consisting of sensory evaluation, aerobic microorganism total yeast, mold, E. coli, and clostridium spp as the followings:

\subsubsection{Total Aerobic Bacteria (TCVN 5165-90 Vietnamese Standards)}

Twenty-five grams of irradiated, non-irradiated, or postirradiated sausage sample was aseptically ground and mixed with $225 \mathrm{ml}$ peptone water into a sterile flask. The content was mixed thoroughly using a sterile glass rod and then serial decimal dilutions were prepared with $0.1 \%$ peptone water. The diluted and undiluted samples were pour plated $(1.0 \mathrm{ml}$, in duplicate) on Plate Count Agar (PCA). The plates were incubated at $37^{0} \mathrm{C}$ for 24 to $48 \mathrm{~h}$ before colonies were counted. Number of colonies was calculated using the following formula:

$$
\mathrm{A}=\frac{N}{\mathrm{n} 1 \times \mathrm{V} 1 \times \mathrm{f} 1+\ldots+\mathrm{ni} \times \mathrm{Vi} \times \mathrm{fi}}(\mathrm{CFU} / \mathrm{g})
$$

Where: $\mathrm{N}$ : total number of colonies

$\mathrm{n}_{\mathrm{i}}$ : number of colonies existing in the test dish $\mathrm{v}$ : volume of solution cultured in each dish $\mathrm{f}_{\mathrm{i}}$ : dilution concentration

\subsubsection{Yeast - Mold}

The previously prepared diluted and undiluted samples were pour plated $(1.0 \mathrm{ml}$, in duplicate $)$ on Sabouraud Dextrose Agar. The plates were incubated at $25^{\circ} \mathrm{C}$ for 5 to 7 days before colonies were counted.

\subsubsection{E. coli}

The previously prepared diluted and undiluted samples were pour plated $(1.0 \mathrm{ml}$, in duplicate) on Brilliant Green Bile Agar. The plates were incubated at $37^{\circ} \mathrm{C}$ for 24 to $48 \mathrm{~h}$ before colonies were counted.

\subsubsection{Clostridium}

The previously prepared diluted and undiluted samples were pour plated $(1.0 \mathrm{ml}$, in duplicate) on Iron Sulfite Agar. The plates were incubated at $37^{\circ} \mathrm{C}$ for 24 to $48 \mathrm{~h}$ before colonies were counted.

Table 1. Scored method under TCVN 3215-79

\begin{tabular}{lc}
\hline Parameters Score interval & Important coefficient \\
\hline Color & 0.25 \\
Structure & 0.35 \\
Smell & 0.20 \\
Taste & 0.20 \\
Total & 1.00 \\
\hline
\end{tabular}

\subsubsection{Sensory Evaluation (TCVN 3215-79)}

The irradiated, or non-irradiated, sausage sample were stored at room temperature $\left(25-27^{\circ} \mathrm{C}\right)$ up to six months and evaluated periodically for its sensory characteristics of color, structure, smell, and taste using Vietnam national standard method (TCVN 3215-79). The evaluation was based on score scale rated in the interval from 1.0 to 5.0 for 4 parameters: color, structure, smell, and taste (Table 1), important coefficient was rated from 0.25 to 1.00 to express the important level of each parameter

The total scores of each parameter were to multiply the score of each parameter and its important coefficient. The last sensory score of product was the total scores of the 4 parameters. If the last sensory score $>=4$, the sample meets the highest quality.

\section{Results and Discussion}

\subsection{Sensory Evaluation}

The results presented in Table 2 and Figure 1, showed that 
the sensory score of the non-irradiated samples gradually decreases on storage time. The highest sensory score of the non-irradiated sample was 3.7 and the lowest score was 2.9; and the score disparity was 0.8 . On the other hand, the highest sensory score of $5.0 \mathrm{kGy} \mathrm{Co}^{60}$ irradiate sample was 4.0 and the lowest score was 3.0, and the score disparity was 1.0 . For 1.0 kGy EB irradiate sample, the highest score was 4.0, and the lowest score was 3.0, the score disparity was also 1.0. The other $\mathrm{Co}^{60}$ irradiated and $\mathrm{EB}$ irradiated samples exhibited similar scores. Overall, sensory score difference among samples was not found significant. Therefore, sensory quality of sausages samples at different irradiation dose was found equally good up to six months of storage in natural condition.

Table 2. The last sensory score of irradiated sausage stored in natural condition during 6 months.

\begin{tabular}{|c|c|c|c|c|c|c|c|}
\hline Samples & Parameters & 1 month & 2 months & 3 months & 4 months & 5 months & 6 months \\
\hline \multirow[t]{5}{*}{ Control } & Color & 0.96 & 0.93 & 0.87 & 0.87 & 0.75 & 0.88 \\
\hline & Structure & 1.20 & 1.23 & 1.17 & 1.19 & 0.98 & 1.28 \\
\hline & Smell & 0.81 & 0.64 & 0.62 & 0.63 & 0.51 & 0.64 \\
\hline & Taste & 0.71 & 0.70 & 0.71 & 0.60 & 0.61 & 0.68 \\
\hline & Last score & 3.70 & 3.5 & 3.4 & 3.3 & 2.90 & 3.50 \\
\hline \multirow[t]{5}{*}{ Gamma 5.0 (G5.0) } & Color & 1.04 & 0.91 & 0.91 & 0.82 & 0.83 & 0.93 \\
\hline & Structure & 1.38 & 1.23 & 1.17 & 1.10 & 1.05 & 1.21 \\
\hline & Smell & 0.81 & 0.68 & 0.61 & 0.53 & 0.57 & 0.60 \\
\hline & Taste & 0.80 & 0.69 & 0.63 & 0.60 & 0.57 & 0.53 \\
\hline & Last score & 4.00 & 3.50 & 3.30 & 3.00 & 3.00 & 3.30 \\
\hline \multirow[t]{5}{*}{ Gamma 2.5 (G2.5) } & Color & 0.96 & 0.94 & 0.84 & 0.85 & 0.77 & 0.90 \\
\hline & Structure & 1.28 & 1.26 & 1.13 & 1.10 & 1.12 & 1.28 \\
\hline & Smell & 0.83 & 0.69 & 0.60 & 0.53 & 0.52 & 0.67 \\
\hline & Taste & 0.71 & 0.76 & 0.70 & 0.55 & 0.60 & 0.61 \\
\hline & Last score & 3.80 & 3.60 & 3.30 & 3.00 & 3.00 & 3.50 \\
\hline \multirow[t]{5}{*}{ Gamma 1.0 (G1.0) } & Color & 1.09 & 0.88 & 0.88 & 0.85 & 0.80 & 0.88 \\
\hline & Structure & 1.20 & 1.21 & 1.20 & 1.05 & 1.05 & 1.24 \\
\hline & Smell & 0.77 & 0.65 & 0.57 & 0.60 & 0.61 & 0.56 \\
\hline & Taste & 0.79 & 0.66 & 0.65 & 0.53 & 0.65 & 0.59 \\
\hline & Last score & 3.80 & 3.40 & 3.30 & 3.00 & 3.10 & 3.30 \\
\hline \multirow[t]{5}{*}{ EB 5.0} & Color & 0.96 & 0.88 & 0.81 & 0.90 & 0.82 & 0.80 \\
\hline & Structure & 1.23 & 1.23 & 1.14 & 1.19 & 1.00 & 1.14 \\
\hline & Smell & 0.87 & 0.71 & 0.63 & 0.61 & 0.57 & 0.60 \\
\hline & Taste & 0.78 & 0.70 & 0.69 & 0.69 & 0.63 & 0.60 \\
\hline & Last score & 3.80 & 3.50 & 3.30 & 3.40 & 3.00 & 3.10 \\
\hline \multirow[t]{5}{*}{ EB 2.5} & Color & 1.05 & 0.90 & 0.89 & 0.87 & 0.75 & 0.88 \\
\hline & Structure & 1.33 & 1.20 & 1.20 & 1.05 & 1.03 & 1.24 \\
\hline & Smell & 0.81 & 0.63 & 0.63 & 0.59 & 0.49 & 0.65 \\
\hline & Taste & 0.84 & 0.66 & 0.71 & 0.61 & 0.60 & 0.65 \\
\hline & Last score & 4.00 & 3.40 & 3.40 & 3.10 & 2.90 & 3.40 \\
\hline \multirow[t]{5}{*}{ EB 1.0} & Color & 1.02 & 0.88 & 0.87 & 0.80 & 0.78 & 0.88 \\
\hline & Structure & 1.38 & 1.13 & 1.16 & 1.17 & 1.14 & 1.28 \\
\hline & Smell & 0.84 & 0.65 & 0.63 & 0.52 & 0.68 & 0.64 \\
\hline & Taste & 0.79 & 0.61 & 0.66 & 0.48 & 0.64 & 0.68 \\
\hline & Last score & 4.0 & 3.3 & 3.3 & 3.0 & 3.2 & 3.50 \\
\hline
\end{tabular}

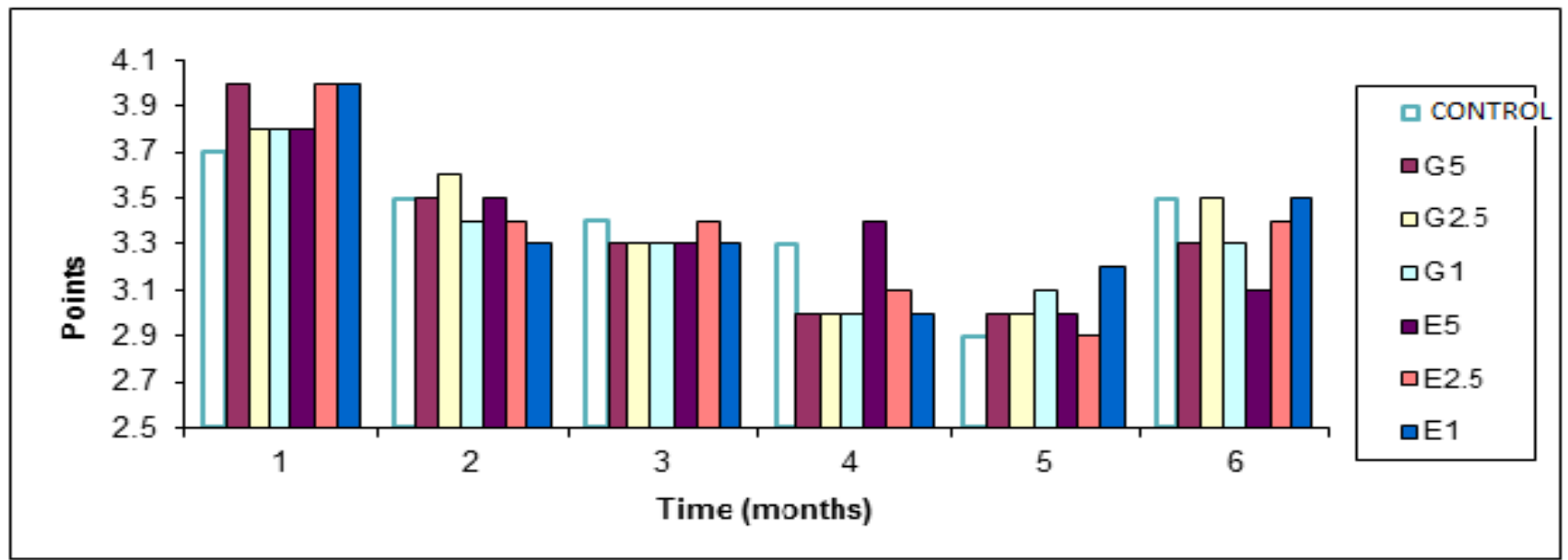

Fig. 1. Sensory total score evaluated by TCVN 3215-79 of the sausages irradiated by gamma and EB with the different doses during 6 months stored in natural conditions in Ho Chi Minh City, Vietnam 


\subsection{Total Aerobic Bacteria (TAB)}

Table 3. TAB of the sausages irradiated stored in natural conditions in HoChiMinh City during 6 months

\begin{tabular}{lcccccccc}
\hline Treatments & $\begin{array}{c}\text { CFU/g } \\
\text { 1month }\end{array}$ & $\begin{array}{c}\text { CFU/g } \\
\text { 2months }\end{array}$ & $\begin{array}{c}\text { CFU/g } \\
\text { 3months }\end{array}$ & $\begin{array}{c}\text { CFU/g } \\
\text { 4months }\end{array}$ & $\begin{array}{c}\text { CFU/g } \\
\text { 4.5months }\end{array}$ & $\begin{array}{c}\text { CFU/g } \\
\text { 5months }\end{array}$ & $\begin{array}{c}\text { CFU/g 5.5 } \\
\text { months }\end{array}$ & $\begin{array}{c}\text { CFU/g 6 } \\
\text { months }\end{array}$ \\
\hline Control & $1.1 \times 10^{2}$ & $<10$ & $<10$ & $<10$ & $7.3 \times 10^{2}$ & $1.4 \times 10^{3}$ & $9.4 \times 10^{2}$ & $3.6 \times 10^{2}$ \\
G 5.0 & 0 & 0 & 0 & $<10$ & $<10$ & $<10$ & $<10$ & $1.9 \times 10^{2}$ \\
Gamma 2.5 & $5 \times 10^{2}$ & $<10$ & $<10$ & $<10$ & $3.4 \times 10^{2}$ & $1 \times 10^{3}$ & $2.9 \times 10^{2}$ & $<10$ \\
Gamma 1.0 & $1.5 \times 10^{2}$ & 0 & 0 & $<10$ & $<10$ & $7.9 \times 10^{2}$ & $<10$ & $<10$ \\
EB 5.0 & $<10$ & $<10$ & $<10$ & $<10$ & $<10$ & $5.7 \times 10^{2}$ & $<10$ & $<10$ \\
EB 2.5 & 0 & $<10$ & $<10$ & $<10$ & $<10$ & $<10$ & $<10$ & $<10$ \\
EB 1.0 & $<10$ & $<10$ & $<10$ & $<10$ & $2.3 \times 10^{2}$ & $2.4 \times 10^{2}$ & $<10$ & $<10$ \\
\hline
\end{tabular}

Data presented in Table 3 showed that number of aerobic bacterial count gradually increase on storage time. The initial $\mathrm{TAB}$ was recorded as $1.1 \times 10^{2} \mathrm{CFU} / \mathrm{g}$ in non irradiated control sample at $1^{\text {st }}$ month of storage and did not increased significantly at $6^{\text {th }}$ month of storage. For irradiated samples there was a decreased trend observed up to 5 months and at $6^{\text {th }}$ month of storage with $5.0 \mathrm{kGy} \mathrm{Co-}{ }^{60}$ irradiated samples showed $1.9 \times 10^{2} \mathrm{CFU} / \mathrm{g}$ population of total aerobic bacteria in the sample. In contrast, other low irradiation dose from the

same source did not show any TAB. This finding suggested that the applied dose did not cover every side of the products. On the other hand, EB irradiated sample showed no bacteria from the first months of storage to the $6^{\text {th }}$ months of storage. From the results, $2.5 \mathrm{kGy}$ and 5.0 EB irradiated samples showed better results compared to other doses of $\mathrm{EB}$ or $\mathrm{Co}^{60}$ sources of irradiated samples.

\subsection{Yeast - Mold}

Table 4. Yeast - mold analysis of the irradiated sausages during 6 months stored at room temperature

\begin{tabular}{|c|c|c|c|c|c|c|c|c|}
\hline Samples & $\begin{array}{l}(\mathrm{CFU} / \mathrm{g}) \\
1 \mathrm{month}\end{array}$ & $\begin{array}{l}\text { (CFU/g) } \\
\text { 2months }\end{array}$ & $\begin{array}{l}\text { (CFU/g) } \\
\text { 3months }\end{array}$ & $\begin{array}{l}\text { (CFU/g) } \\
\text { 4months }\end{array}$ & $\begin{array}{c}\text { (CFU/g) } \\
\text { 4.5months }\end{array}$ & $\begin{array}{l}\text { (CFU/g) } \\
\text { 5months }\end{array}$ & $\begin{array}{c}\text { (CFU/g) } \\
5.5 \text { months }\end{array}$ & $\begin{array}{l}\text { (CFU/g) } \\
\text { 6months }\end{array}$ \\
\hline Control & $1.1 \times 10^{2}$ & $<10$ & $<10$ & $<10$ & $<10$ & $<10$ & $4.5 \times 10^{2}$ & $2.2 \times 10^{2}$ \\
\hline Gamma 5.0 & 0 & 0 & 0 & $<10$ & $<10$ & $<10$ & $<10$ & $<10$ \\
\hline Gamma 2.5 & $8.2 \times 10^{2}$ & $<10$ & $<10$ & $<10$ & $<10$ & $<10$ & $<10$ & $<10$ \\
\hline Gamma 1.0 & 0 & 0 & 0 & $<10$ & $3.2 \times 10^{2}$ & $3.5 \times 10^{2}$ & $<10$ & $<10$ \\
\hline EB 5.0 & $<10$ & 0 & 0 & $<10$ & $<10$ & $<10$ & $<10$ & $<10$ \\
\hline EB 2.5 & 0 & $<10$ & $<10$ & $<10$ & $2 \times 10^{2}$ & $2.3 \times 10^{2}$ & $<10$ & $1.7 \times 10^{3}$ \\
\hline EB 1.0 & 0 & $<10$ & $<10$ & $<10$ & $<10$ & $<10$ & $<10$ & $<10$ \\
\hline
\end{tabular}

The non irradiated control samples showed yeast \& mold growth at the first months analysis results (Table 4). However, irradiated samples did not show any yeast $\&$ mold at the first months of analysis. This finding suggested that the number of yeasts and mold colonies in the control samples was much more than that of the irradiated samples. Data presented in table 4 also demonstrated that irrespective of irradiation sources, $5.0 \mathrm{kGy}$ dose of irradiation was able to inactivate the yeast and mold successfully and thus, did not appear in the medium.

\subsection{E. coli and clostridium spp.}

Table 5. Quantification analysis of E. coli and Clostridium in the irradiated sausages during six months stored in natural conditions in HCM City.

\begin{tabular}{|c|c|c|c|c|c|c|c|}
\hline Samples & Parameters & $\begin{array}{c}\text { (CFU/g) } 1 \\
\text { month }\end{array}$ & $\begin{array}{c}(\mathrm{CFU} / \mathrm{g}) 2 \\
\text { months }\end{array}$ & $\begin{array}{c}\text { (CFU/g) } 3 \\
\text { months }\end{array}$ & $\begin{array}{c}(\mathrm{CFU} / \mathrm{g}) 4 \\
\text { months }\end{array}$ & $\begin{array}{c}(\mathrm{CFU} / \mathrm{g}) 5 \\
\text { months }\end{array}$ & $\begin{array}{c}(\mathrm{CFU} / \mathrm{g}) 6 \\
\text { months }\end{array}$ \\
\hline \multirow[t]{2}{*}{ Control } & E. coli & 0 & 0 & 0 & 0 & 0 & $<10$ \\
\hline & Clostridium & 0 & 0 & 0 & 0 & 0 & 0 \\
\hline \multirow[t]{2}{*}{ Gamma 5.0} & E. coli & 0 & 0 & 0 & 0 & 0 & $<10$ \\
\hline & Clostridium & 0 & 0 & 0 & 0 & 0 & 0 \\
\hline \multirow[t]{2}{*}{ Gamma 2.5} & E. coli & 0 & 0 & 0 & 0 & 0 & $<10$ \\
\hline & Clostridium & 0 & 0 & 0 & 0 & 0 & 0 \\
\hline \multirow[t]{2}{*}{ Gamma 1.0} & E. coli & 0 & 0 & 0 & 0 & 0 & 0 \\
\hline & Clostridium & 0 & 0 & 0 & 0 & 0 & 0 \\
\hline \multirow[t]{2}{*}{ EB 5.0} & E. coli & 0 & 0 & 0 & 0 & 0 & $<10$ \\
\hline & Clostridium & 0 & 0 & 0 & 0 & 0 & 0 \\
\hline \multirow[t]{2}{*}{ EB 2.5} & E. coli & 0 & 0 & 0 & 0 & 0 & $<10$ \\
\hline & Clostridium & 0 & 0 & 0 & 0 & 0 & 0 \\
\hline \multirow[t]{2}{*}{ EB 1.0} & E. coli & 0 & 0 & 0 & 0 & 0 & $<10$ \\
\hline & Clostridium & 0 & 0 & 0 & 0 & 0 & 0 \\
\hline
\end{tabular}


The E. coli and Clostridium spp, was not found in any samples stored in natural conditions for 6 months. However, in case of their presence, they might survive or grow during the long storage; therefore application of irradiation could maintain the safety of the sausages. By comparing the other parameters, the $5 \mathrm{kGy}$ dose irrespective of irradiation sources could inactivate pathogen by extending the shelf-life at room temperature.

\section{Conclusion}

The study results concluded that irrespective of the irradiation sources, application of 5.0kGy dose of irradiation was able to extend the shelf life of ready to eat sausages up to six months at natural condition without compromizing the microbial and sensory qualities of the products. Thus, this irradiation technology could be applicable in extending the shelf life of meat products. However further research is needed to evaluate the influences of $5.0 \mathrm{kGy}$ irradiation dose on bio-chemical composition, including oxidation of fat, protein and other nutrient.

\section{References}

[1] Bari, M. L., C. Sommers, A. Fumiko, S. Todoriki, and S. Kawamoto (2006). Irradiation Inactivation of Listeria monocytogenes in Low Fat Ground Pork at Frozen and Refrigerated Temperature. J. Food Prot. Vol 69 (12): 29552960.
[2] FDA(The U.S. Food and Drug Administration) 1997. Federal Register. 1997. Irradiation in the production, processing, and handling of food. Fed. Regist. 62:64107-64121.

[3] Jo, C., S. K. Jin, D.U. Ahn, 2000. Color changes in irradiated cooked pork sausage with different fat sources and packaging during storage, Meat Science 55 (2000) 107 \pm 113.

[4] Jo, C., D.U. Ahn, M.W. Byun, 2002. Irradiation-induced oxidative changes and production of volatile compounds in sausages prepared with vitamin E-enriched commercial soybean oil, Food Chemistry 76 (2002) 299-305.

[5] Thuoc Tran Linh, 2006. Methods of microbiological analysis of water, food and cosmetics. Training and educational Publishing House Vietnam, 2006.

[6] QCVN 8-3: 2012/BYT, 2012. National Technical Regulation on microbiological contamination in food, published by Vietnam Ministry of Health

[7] Decision No. 3616/2004/QĐ-BYT, 10, 14th, 2004, Safety regulation for food preservation by irradiation, published by Vietnam Ministry of Health 2004

[8] TCVN 5165 - 90 Food products. Methods for determination of total aerobic bacteria.

[9] TCVN 7247: 2003 (CODEX STAN 106-1983). Food irradiation - General requirements.

[10] TCVN 3215:1979 Food products- Sensory analysis- Methods of scoring, Published by Committee of Sciences and Techniques Vietnam 1079. 